\title{
Clamor Schürmann's contribution to the ethnographic record for Eyre Peninsula, South Australia
}

\author{
Kim McCaul
}

The Barngarla native title claim, ${ }^{1}$ which received a largely positive determination from the Federal Court in 2014, covered an area that essentially corresponds to the eastern part of Eyre Peninsula in South Australia, from just north of Port Augusta to Sleaford Bay, south of Port Lincoln (see Map 3.1). The determination followed a contested trial that carried with it the usual forensic analysis of both contemporary Aboriginal evidence and the ethno-historical record.

Because native title law requires a comparison of the present system of 'laws and customs' with that maintained by the claimants' ancestors at the time of sovereignty, the early ethnographic record is especially sought after in such matters. It is rare, however, for this record to include material that is both as close to first contact and as detailed as that produced by the Lutheran missionary Clamor Schürmann.

This chapter will briefly contextualise Schürmann's ethnographic activities and provide an overview of some of the key elements of his record, which consists of significant linguistic, anthropological and historical data.

1 Croft on behalf of the Barngarla Native Title Claim Group v State of South Australia [2015] FCA 9. 


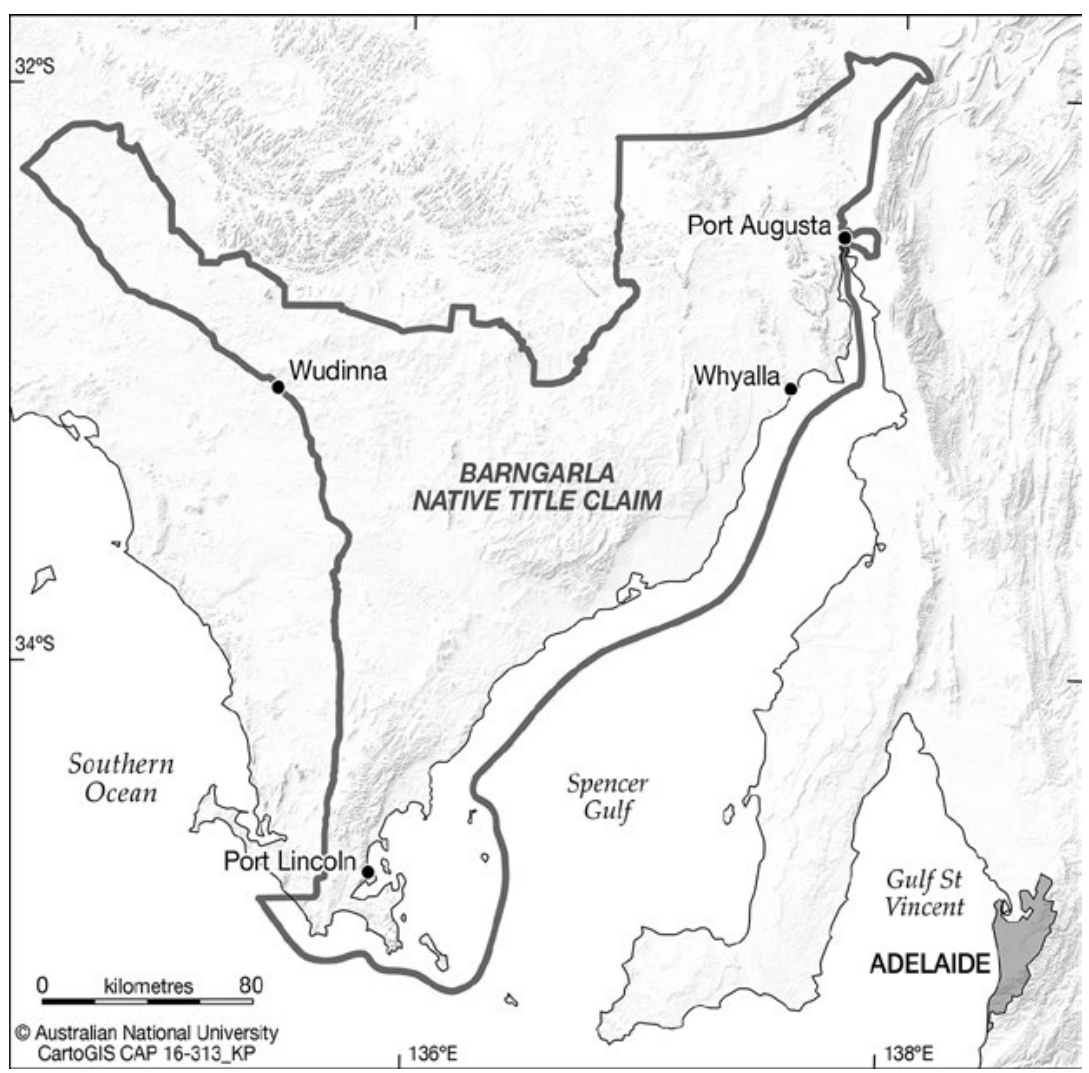

Map 3.1 Barngarla native title claim area.

Source: CartoGIS, The Australian National University.

\section{Clamor Schürmann and the Lutheran ethnographic tradition}

Clamor Schürmann was born in June 1815 in Schledehausen near Osnabrück, in what is today the state of Lower Saxony. He entered a missionary seminary in Berlin in July 1832. In 1836, he entered the seminary of the Evangelical Lutheran Mission Society of Dresden together with Gottlieb Teichelmann, his future collaborator in Australia. Two years later, Schürmann and Teichelmann left for South Australia, where they arrived on 12 October and immediately began work in Adelaide (Lockwood 2011). While their brief missionary work was fraught with setbacks and by all measures unsuccessful, their work on the language of the Adelaide Plains (Teichelmann and Schürmann 1840) eventually 
became a crucial source for language reclamation (Amery 2000). It also marked the beginnings of the remarkable contribution Lutheran missionaries made to the ethnographic record of South Australia.

In addition to Teichelmann and Schürmann's work on Kaurna and Schürmann's solo work on Barngarla, which I will discuss here, their colleague Heinrich Meyer produced linguistic and ethnographic material about the language and culture of the Ramindjeri and other Ngarrindjeri peoples of the Encounter Bay area, where he attempted missionary work in the 1840s (Meyer 1843, 1846).

Starting in the 1870s, a new wave of Lutherans began work in Central Australia: first, at Killalpaninna Mission on Cooper Creek among the Diyari people, and, later, at the famous Hermannsburg Mission among the Arrernte. Otto Siebert, Johann Georg Reuther and Carl Strehlow produced the most significant ethnographic contributions from this era. Siebert and Reuther both conducted extensive ethnographic work with the peoples at Killalpaninna, the former in close communication with A. W. Howitt, which resulted in a number of publications (Howitt and Siebert 1904; Howitt 1996, in which Siebert is acknowledged as a major informant; Siebert 1910).

Siebert's colleague and rival Reuther was unable to publish his own ethnographic work in his lifetime, but he produced an incredible multivolume oeuvre that provides unique insights into traditional life among the Diyari and neighbouring peoples (Reuther 1976) and has been the source of much analysis by subsequent researchers (e.g. Hercus and Potezny 1991; Jones 2002; Jones and Sutton 1986). Finally, while only published in German and still not fully translated into English, the work of Carl Strehlow on Arrernte culture and language is widely known among anthropologists, because of his rivalry with Baldwin Spencer and indirectly due to the subsequent work of his son, T. G. H. Strehlow (1907-20, see also 1971; Kenny 2013).

This Lutheran ethnographic legacy is no coincidence. At a time when anthropology had not yet developed as a formal discipline (Meyer, Schürmann, Teichelmann) or was essentially in its infancy (Reuther, Siebert, Strehlow), the motivation of these young Germans to enter the cultural world of Aboriginal people arose directly from a missionary philosophy that required spreading the word of God in the language of the people whose conversion was sought. And this meant not only using 
the words of that language, but also being sufficiently fluent in the local cultural lexicon so as to be able to adapt one's teaching to the existing world view and judge what to combat as anti-Christian and what to accept as anodyne (Völker 1999: 9). Due to their own priorities, this inspired the missionaries to learn about Aboriginal marriage laws, ceremonial life and religious beliefs_-all essential areas of anthropological inquiry.

In Schürmann's case at least, one other factor that helped him establish a rapport with Aboriginal people seems to have been that he genuinely saw them as equal human beings at a time when for so many other Europeans they were something lesser. This is reflected not only in the compassion with which he reports some of the deaths he witnessed and in the friendships he seems to have developed, but also in the large number of personal Aboriginal names found in his correspondence. While so many early European commentators would only identify Aboriginal people by imposed and at times demeaning European names, or even in formal correspondence refer to grown men as 'boys' and women as 'gins', Schürmann consistently identifies the people he is talking about by their own names, reflecting a respect and familiarity that explain the detail available in his ethnographic text.

\section{Schürmann's complex social positioning}

The Lutheran approach to the missionary enterprise was extremely frugal. Essentially, missionaries were expected to be financially self-sufficient or obtain donations from local Lutherans (Lockwood 2011: 25). There was no institutional fund as such. As a result, the missionaries were heavily reliant on assistance from the colonial government. Yet the relationship with the government was complex. On the one hand, the missionaries felt they were providing a service to the government by assisting in the education of the Aboriginal population, but, on the other, they strongly and at times vocally disagreed with English colonial policy (Lockwood 2011: 22). And, from the perspective of the English authorities, the position of German Lutheran missionaries always seems to have been ambiguous. Schürmann and Teichelmann had befriended South Australian governor George Gawler on their voyage to Australia and originally received some support in setting up the 'Native Location' in Adelaide for the purposes of providing a European education to Aboriginal children, but this support was soon withdrawn in favour of an English boarding school. This pattern 
was to be repeated on Eyre Peninsula, where, after years of service on a meagre wage, Schürmann saw his position usurped by a generously funded Anglican mission (Lockwood 2011).

When Schürmann moved to Port Lincoln in 1840, his support from the governor was contingent on him assisting the authorities as interpreter and liaison with the Barngarla and $\mathrm{Nawu}^{2}$ people of the peninsula. Eyre Peninsula had been colonised only in the previous year and Schürmann witnessed significant early frontier conflict between the colonisers and the original inhabitants. His first encounter with Aboriginal people, as recorded in his correspondence, was with a group of nine men who came to camp at Port Lincoln. With an ethnographer's eye already trained from his work with diverse Aboriginal peoples around Adelaide, his description of this meeting noted that the men were circumcised and had long beards plaited together and wrapped with grey fur. ${ }^{3} \mathrm{He}$ also noted that even though some words seemed similar to the 'Adelaide language', he could not really make himself understood. According to Schürmann's subsequent letter to Gawler, the men were beaten and arrested by police in supposed connection with the recent murder of a shepherd, even though it was clear that they had nothing to do with that incident (Schurmann 1987: 117-18).

This harsh introduction set the tone for the next five years of Schürmann's work around Port Lincoln. Aboriginal violence against settlers-often committed by inland peoples who withdrew after the attacks-was met with indiscriminate retaliation by the English authorities. And Schürmann was caught in the middle, expected on the one hand to liaise with the Aboriginal people, only to have his subsequent advice about guilt and innocence ignored by the authorities in favour of summary executions. This in turn undermined the trust he was trying so hard to build with the Barngarla and Nawu people. On one occasion when Schürmann accompanied a group of soldiers in pursuit of the murderers of a colonist, the troopers shot an innocent man whom Schürmann had befriended. Schürmann left the party in disgust, 'feeling it inconsistent with my missionary character and good faith with the natives to witness such actions' (Schurmann 1987: 151-2).

2 The name of this group is often spelt Nauo in the literature, but I spell it Nawu in accordance with the contemporary orthography of the languages in this area.

3 He would have noted their circumcision as significant, because not all the peoples he met around Adelaide practised that custom. 
While beyond the scope of this chapter, there are numerous passages like the following in Schürmann's correspondence that would offer rich material for a history of the frontier conflict on Eyre Peninsula:

This morning I went to see the natives released from captivity to find out about them for myself. Wornama told me that the following natives had been shot: Ngulga, Munta, Tubu, and two children named Tyilye and Tallerilla, aged ten and 12 years. Munta and Tubu accompanied us to Mallei (in the search party which left on April 2), and the former was in my house when the news arrived of Biddle's murder. So heinous are the Whites! Mr Driver said the butchery will continue until they hand over the guilty ones. But it hasn't even been proved that the guilty ones are among them. It is possible, as they insist, that the real murderers are somewhere in the north. (Schurmann 1987: 152)

Not only do his data provide an insight into an often-ignored violent aspect of South Australia's colonial history, they also show the complex dynamics of the broader Aboriginal polity, which was not in agreement on whether or not to resist colonial invasion by force, and was trying to maintain its regular social and economic life patterns in the face of dramatic and rapid social changes. This chapter, however, is not the place for this analysis.

One thing is certain: for most contemporary anthropologists, it is hard to imagine the working conditions Schürmann had to contend with, which makes his ethnographic productions even more remarkable.

\section{Schürmann's ethnographic contributions}

Schürmann's record consists of two major publications, both published in English. A grammar and vocabulary (Schürmann 1844) and an ethnographic account covering such varied details as material culture, initiation ceremonies and mythological stories (Schürmann 1879). In addition, Schürmann wrote a significant number of letters containing interesting historical and cultural information. Much of this correspondence was translated and compiled by a descendant (Schurmann 1987), although some important pieces of information remain unpublished in the Lutheran Archives in Adelaide (Schürmann $1840-45)$. 


\section{Linguistics}

I will not comment in detail here on Schürmann's linguistic work. It is discussed by Hercus and Simpson (2001), who make the following comments:

Schürmann's dictionary contains over 3,000 head words ... He notes about seventy-six synonyms or paraphrases (distinct from variant forms), but there are many more. The surprisingly high number indicates a conflation of dialects, perhaps of the coastal and the scrub-gum people dialects of Barngarla, but perhaps also of Nauo. This is suggested by pairs such as kuma, kubmanna 'one' and kuttara, kalbelli 'two' in which one member of the pair is definitely Nauo, but also by pairs such as kappa, kulbarri 'three', kapi, kauo 'water', and mialla, mena 'eye' in which one member is shared with Wirangu. (Hercus and Simpson 2001: 283)

Hercus and Simpson engaged with his work primarily for the purpose of re-creating the Nawu language, but, more recently, Schürmann's record has provided the foundation for contemporary Barngarla language revival, initiated by the community in 2012 .

\section{Social data}

In his paper on the social organisation of South Australian tribes, R. H. Matthews acknowledged Schürmann's 1846 account of the two intermarrying matrimoieties found among the Barngarla as:

the first accurate record of the divisions of aboriginal tribes, not only in the colony mentioned, but in any part of the Australian continent. Owing to this priority and convenience of reference I have adopted the name of the Parnkalla tribe for the whole nation. (Matthews 1900: 79)

Matthews's 'nation' encompassed essentially the entire north-east of South Australia - the area that was subsequently termed the 'Lakes cultural bloc' by Elkin in the 1930s (Elkin 1931). The Barngarla are located at the southwestern-most extent of his cultural bloc and Schürmann's was the first account to identify numerous key cultural features defining this region, including a particular set of initiatory ceremonies known as wilyaru, which he describes in unparalleled detail (Schürmann 1879: 231-4). 
Many years after Matthews, one of Australia's most eminent anthropologists was less flattering of Schürmann's work. Despite relying heavily on Schürmann for his chapter on the Aboriginal culture of Eyre Peninsula, Ronald Berndt (1985: 127) described his work as 'not based on systematic anthropological enquiry' and 'often misleading'.

The basis for Berndt's casual dismissal of Schürmann's work is not apparent from Berndt's article. He does not elaborate on where he thinks Schürmann's information is misleading and, for the most part, simply reproduces material from Schürmann's 1846 publication.

One area where Berndt's article explores questions not contemplated by Schürmann is a discussion of hypothetical historical migrations across Eyre Peninsula. In Berndt's view, Barngarla people migrated down Eyre Peninsula following European colonisation, gradually pushing southward the original Nawu population. As this view is of direct relevance to the native title inquiry into the ongoing connection between people and land, it was naturally canvassed before the court. Schürmann's material was fundamental in refuting Berndt's thesis. But before discussing this issue in more detail, I will give a brief outline of some other details in Schürmann's data.

While much of what Schürmann points out about Aboriginal societyfor example, its acephalous social structure-has since become a given in our understanding of these societies, his work pre-dated any detailed observations published to that point and as such was groundbreaking.

Schürmann referred to the lack of clear leadership structures, with some ethnocentric judgement:

It is a curious fact, as well as a strong proof of the degraded social condition of the aboriginal inhabitants of this country, that they have no chief, or any persons of acknowledged superior authority among them. All grown up men are perfectly equal, and this is so well understood that none ever attempt to assume any command over their fellows; but whatever wishes they may entertain with regard to the conduct and actions of others, they must be expressed in the shape of entreaty or persuasion. Considerable deference, however, is shown to the old men by the younger generation, proceeding, perhaps, partly from the respect which superior age and experience inspire, but greatly increased and kept up by the superstitious awe of certain mysterious rites, known only to the grown up men, and to the knowledge of which the young are only very gradually admitted. (Schürmann 1879: 226) 
Schürmann's negative views of the lack of hierarchy among the Aboriginal people may simply reflect his Germanic background, but from his correspondence with the mission authorities it appears that his feelings may also have been tainted, because the absence of social stratification posed added challenges to his missionary work. Thus, in a letter to his mission society on 3 July 1843 , Schürmann complained about the difficulty of converting Aboriginal people, caused by the way they roamed about and the fact they could not be controlled in any way, saying:

If they had chiefs or just recognized some kind of authority through which one could effect uniformity in their movements and actions, much or even all could be achieved. But as long as each one is unfettered master of himself, I see this desirable goal as remaining unobtainable. (Schürmann 1840-45: 170; my translation)

Elsewhere, Schürmann provides a brief synopsis of daily camp life that captures the practical impacts of this lack of social leadership and at the same time could have served nicely as an exemplar for Sahlins's 'original affluent society' (Sahlins 1972):

They seem never in a hurry to start in the morning, and it usually requires a great deal of talking and urging, on the part of the more eager, before a movement is made. When arrived at the camp, which is always some time before sunset, the first thing to be done is to make a fire and roast the small animals that they may have killed (kangaroo and other large game, being roasted on the spot where it is killed, and what is not eaten then, carried piece-meal to the camp.) After the meat is consumed, the women produce the roots or fruit picked up by them during the day; and this dessert also over, the rest of the evening is spent in talking, singing or dancing. (Schürmann 1879: 221)

Such detailed firsthand insights into the everyday life of an Aboriginal population so close to pre-contact are rare indeed.

Name avoidance of the deceased and beliefs in spiritual punishments are two well-known features of classic Aboriginal society that Schürmann illustrates with a level of insight well beyond what is commonly found in material that pre-dates formal anthropological inquiries. Regarding the former, which early commentators would often deride as deriving from superstitions, he offers an emic logic focused instead on human emotions, richly illustrated with practical implications: 
Never, upon any account, is the name of the deceased mentioned again for many years after, not from any superstition, but for the professed reason that their mournful feelings may not be excited, or, to use their own expression, 'that it may not make them cry too much.' If they have occasion to allude to dead persons, it is done by circumlocution, such as these: I am a widower, fatherless child, childless, or brotherless, as the case may be, instead of saying: my wife is dead, my father, child or brother is dead. If a death occurs among them in the bush, it is with great difficulty that the name of the deceased can be ascertained. In such a case, the natives will remind you of incidents that may have happened in his lifetime, that he did such a thing, was present on such an occasion, \&c., but no persuasion on earth will induce them to pronounce his name. (Schürmann 1879: 247-8)

The belief that bad things will happen to people who misbehave is a common feature of contemporary Aboriginal culture, where illness and accidents are often attributed to some kind of socially unacceptable conduct. Schürmann documents the ancient origins of this belief with an example that shows that it was not culturally limited to Aboriginal people but considered a universal principle:

[T] hey seem to think that the fate of man in this world is in some degree dependent on his good or bad conduct. The following anecdote will best illustrate their views on the subject: It was reported by a native that at or near Streaky Bay a black man had been shot by a whaling party for spearing a dog belonging to them, and which had been furiously attacking the native; some time after, the crew of a whaler wrecked in that neighbourhood came overland to Port Lincoln, and when it was hinted that perhaps one of them had shot the black man, the natives at once assigned that act of cruelty as the cause of the shipwreck. (Schürmann 1879: 235)

From an applied anthropological perspective, it is significant that both these cultural insights are easily referenced in contemporary culture. Even if name avoidance may have become less absolute, it is still readily observed; in my experience of interviewing Aboriginal people about their family history, the names of deceased people are regularly avoided unless directly prompted for.

Such examples of continuity are important in legislative frameworks of not only native title, but also heritage laws that include requirements of 'traditionality' and cultural continuity. In other words, Aboriginal people are regularly required to demonstrate their cultural authenticity 
when seeking recognition of some form of rights under the AngloAustralian legal system. As such, being able to identify traditional practices that have clear contemporary counterparts is very valuable.

The ability to demonstrate continuity is especially important in practices relating to land, which in Aboriginal society essentially amount to religious practices, an area of logical interest to Schürmann. He recorded initiatory practices in remarkable detail and was able to personally witness a thirdstage initiation practice that is known as wilyaru across much of eastern South Australia (Schürmann 1879: 231; Elkin 1931: 53).

More relevant to the question of continuity in relationship to land, however, is a passing observation Schürmann makes regarding the importance of areas associated with an earlier stage of initiation. On Eyre Peninsula, as across much of settled Australia, actual initiation ceremonies have been in abeyance for a couple of generations (although men are still sometimes initiated elsewhere). However, it is common for people to know areas that were traditionally associated with initiation ceremonies and consider them to be culturally restricted. In contemporary contexts, the underlying approach to Aboriginal people by non-Aboriginal laypeople (in the context of land access issues, these are most commonly mining company or government representatives) is often tainted by preconceptions regarding cultural loss. Against this backdrop, when Aboriginal people emphasise the importance of initiation sites, despite the fact that initiations are no longer practised, this can be interpreted as an attempt to re-create cultural significance in the face of fundamental loss. However, in one brief passage, Schürmann's record establishes that the significance of such places has a deeply traditional origin:

To illustrate how early and systematically the native children are trained to view these ceremonies [referring to Warrara or circumcision ceremonies] with feelings of awe, it may be mentioned, that they are never allowed to approach the spot where a warrara has been made; if such a place should happen to fall in the line that the men are traveling, the little boys are directed to take a round, in order to avoid the sacred spot. (Schürmann 1879: 228)

Any contemporary restrictions on accessing such historical initiation sites clearly have traditional foundations. 


\section{Creation narratives}

When it comes to the actual creation narratives that we now know fundamentally underpin the Aboriginal relationship to land, Schürmann's work was unfortunately hampered by his cultural preconceptions. Schürmann bookended the handful of abbreviated creation narratives that he published with the following comments, first at the introduction: 'The Aborigines have a great number of fabulous traditions handed down to them by their forefathers, all of which are characterized by a high degree of improbability and monstrosity' (Schürmann 1879: 238).

And he follows his accounts with this conclusion: 'The natives have many more similar tales among them; the above ... will be sufficient to show their monstrous and in every respect ridiculous character' (Schürmann 1879: 241).

It is almost as if Schürmann feared that his audience might think he in some way endorsed or accepted the accounts if he did not deride and belittle them. He adopts the same tone in a letter to his mission society:

The original concepts of the Aborigines regarding religious matters are very childish and often so meaningless that one spends a lot of time doubting that one has properly understood them. About the origin of visible nature they do not seem to have any concept, or at least they always respond to questions about this as though everything had come into being by itself, while the creation of some particular things is tied to some very ridiculous fairytales. For example, they attribute the creation or separation of the ocean from the land to two women, who some time ago came from the far north and caused the separation of land and water by throwing their sticks (such as are still today used to dig up roots). (Schürmann 1840-45: 178; my translation)

This prejudice against Aboriginal creation narratives would persist among Lutheran clergy and dominate some of the correspondence between missionaries and their society in the 1880s and 1890s (e.g. Hercus and McCaul 2004: 36).

While it is tempting to lament the lost opportunity of establishing a comprehensive record of creation narratives for Eyre Peninsula caused by this prejudice, it is more productive to focus on what was recorded. In his published record, Schürmann documented four stories (1879: 238-41; also reproduced in Berndt 1985: 132). They are already in the record, but I will mention two here because during the Barngarla native 
title hearing claimants gave evidence about these stories that was clearly not derived from Schürmann's work, thereby establishing important continuities.

The first one concerns the actions of an ancestral man now linked to thunder and lightning on the southern part of Eyre Peninsula:

Pulyállana was in days of yore a great man, who conferred on succeeding generations the benefit of having given names to many localities in the southern and western parts of this district, which they retain to this day.

He had, however, the misfortune to lose both his wives, who absconded from him —an event that by no means contributed to keep him in good humour. After a great deal of fruitless search he at last hit upon their track, and, following it; overtook them somewhere about Cape Catastrophe, where they were both killed by him. They were then converted into stone, together with their children, and all may be seen there at the present day in the shape of rocks and islands; and their breathing and groaning be heard in a cave, into which the roaring sea rushes a long way underground. Pulyallana himself was subsequently raised in the sky, at or near Puyundu (the native name for Cape Sir Isaac) where he is sometimes seized with violent fits of rage. On such occasions he raves and storms about among the clouds, and keeps shouting most lustily ... thus producing what is commonly called thunder ... The lightening is also his production, being caused by the sudden jerking or opening of his legs in his furious gestures. (Schürmann 1879: 238-9)

The second story concerns marnpi ('pigeon') and tata ('bat'):

Between Coffin's and Sleaford Bays there is a line of bare, white sandhills, erroneously laid down in Flinders' map as white cliffs. These masses of drifting sand have most probably been piled up by the westerly gales, which often now alter their shape and position; but, according to a tradition of the natives, they were raised by Marnpi and Tatta, two of their ancestors. A great fire, coming from the ocean, spread far and wide on the sea-coast, and seemed likely to envelop the whole country in its flames. Deliberating how to prevent such a calamity, it occurred to the abovementioned personages, that the best method of quenching the fire would be to bury it; they accordingly betook themselves to the task, and, in executing it, threw up those sandhills which testify to this day the vastness of the undertaking. (Schürmann 1879: 240-1) 
In 2014, claimants gave evidence of both of these stories in terms suggesting convincingly that they had learned them from the previous generations. As such, Schürmann's record played the important role of evidencing the antiquity of the narratives, which clearly pre-date the arrival of Europeans in Australia.

I will now turn to the issue of population movement, about which Berndt expressed such definitive views in his account of traditional Aboriginal life on Eyre Peninsula.

\section{Berndt's migration hypothesis}

In his desktop study of Eyre Peninsula Aboriginal people, Berndt argued that there had been substantial population movement across the peninsula from the very beginning of European colonisation. In the native title claim, this argument was essentially expressed as representing a Barngarla population shift into much of their claim area, potentially post-sovereignty. Because native title rights and interests claimed today must arise from rights and interests enjoyed by the claimants' ancestors at the time of sovereignty, this argument could have been fatal to the native title claim. Berndt summarised his views as follows:

According to the available information, then, while the Gugada traditionally came as far south as the north-western end of the Gawler Ranges and to at least part of Lake Gairdner, they were also spreading from the north-west into Eyre Peninsula prior to 1850. The evidence dealt with in this paper suggests that culturally, if not socially, they virtually overwhelmed, especially the Wirangu, and were certainly making inroads into both Banggala and Nauo territories. On the northeastern side of the Peninsula, the Banggala were being forced southward to take over Nauo land. The Wirangu, essentially not a Western Desert population, had been forced southward by expanding Desert groups. While the Nauo were obviously influenced by (if not culturally akin to) the Banggala, it is tempting to speculate that the Wirangu and Nauo were protohistorically the original inhabitants of a large part of the Peninsula. The Banggala belonged culturally to the lakes Eyre and Torrens groups ... They traditionally occupied the northeastern sector of the Peninsula ... Nevertheless, on the face of the evidence available to us today, we must conclude that at the time of early European settlement on the Eyre Peninsula the two dominant Aboriginal socio-cultural systems were Banggala and Gugada. (Berndt 1985: 128) 
A map that graphically illustrates Berndt's migration theory accompanies his article (Map 3.2).

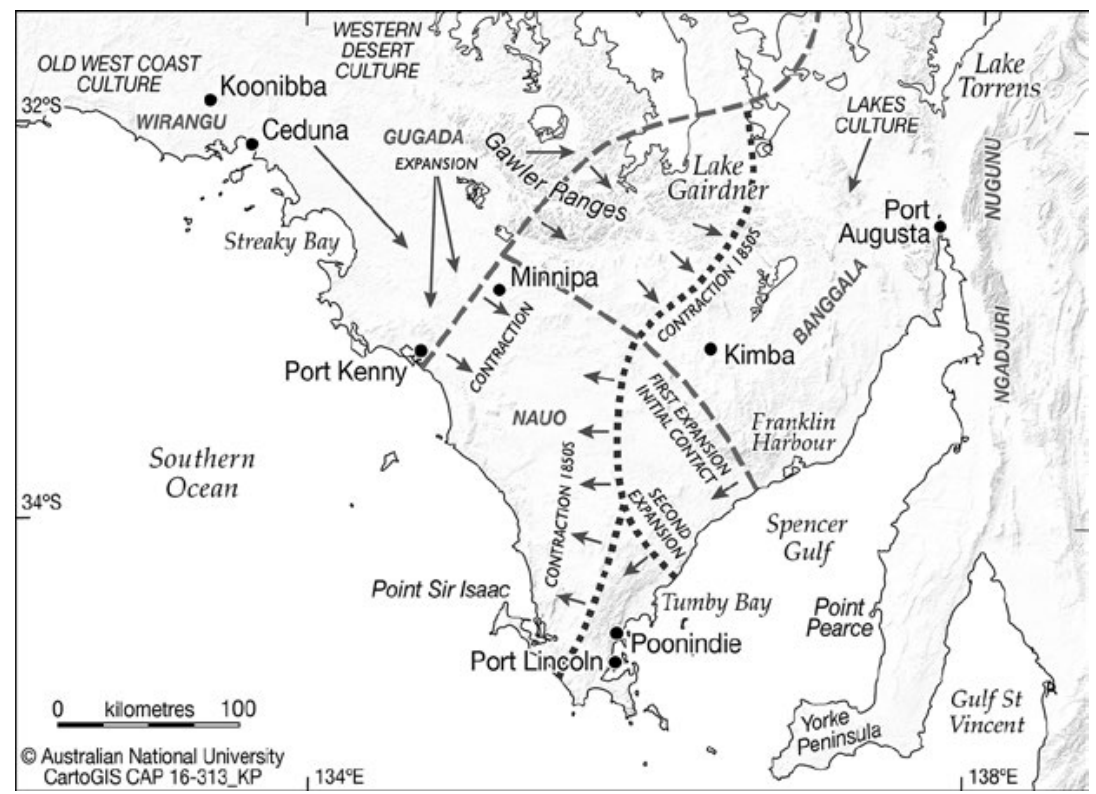

Map 3.2 Berndt's map showing the expansion and contraction of Aboriginal groups on Eyre Peninsula at the time of early European settlement.

Source: CartoGIS, The Australian National University, after Berndt (1985: 129).

Unfortunately, Berndt does not actually identify the information and evidence alluded to in the above quote that supports such major social movements. As his theory closely mirrors accounts found in Tindale (1974), one has to assume that Berndt was influenced by those. Tindale makes relevant comments in his catalogue entries for both $\mathrm{Nawu}$ and Barngarla. Under Barngarla, Tindale claims:

Prehistoric and protohistoric pressure from the Kokata was modifying their northern boundary, causing a shift of their southern limits also between Port Augusta and the Gawler Ranges down towards Franklin Harbour. In their last years they ventured as far south as Tumby Bay to obtain whipstick mallee wood for spears (Hossfeld). After white settlement they lived around Port Lincoln where both Schürmann and Wilhelmi studied them. (Tindale 1974: 216) 
Correspondingly, under Nawu, he asserts the following:

Pressure from Pangkala was causing contraction to southwest at time of early white settlement; their protohistoric boundary ran from about the Gawler Ranges to Port Augusta; extinct, all my data from Wirangu and Pangkala informants. (Tindale 1974: 214)

Schürmann arrived on Eyre Peninsula as part of the first wave of permanent colonisation, one year after Port Lincoln was established. If the sudden presence of Europeans had caused major population shifts, Schürmann did not perceive it. His published work testifies to a seemingly stable situation on Eyre Peninsula, and does not support Berndt's suggestion that Barngarla and Kukata were the dominant Aboriginal sociocultural systems at the time of early European settlement:

The Aborigines inhabiting the Peninsula of Port Lincoln are divided into several tribes, with two of whom the European settlers are in daily contact, namely, the Nauo and Parnkalla tribes. Besides these, three other tribes are mentioned by the natives as known to them: the Nukunnus in the north-east, the Kukatas in the north-west, and the Ngannityiddis in the north, between the last two mentioned of whom a few have now and then visited the settlement. All these tribes seem in general to be on tolerably good terms with each other, at least it does not appear that there are any hereditary feuds between them, such as exist in other parts of the colony. It is true that the Kukatas are universally feared and abominated, but apparently more on account of their reputed skill in witchcraft and various other dangerous tricks than for their warlike qualities. (Schürmann 1879: 248-9)

In his unpublished writings, Schürmann provided additional details that allow further appreciation of the traditional demographics of Eyre Peninsula. In a letter of 18 May 1842 to the Protector of Aborigines, Matthew Moorhouse, Schürmann provides the following account of the distribution of tribes around Port Lincoln:

The natives of Port Lincoln are divided into two principal tribes called in their own languages the one Nauo + the other Parnkallas. The former of these frequent the coast to the south and west of the settlement + live chiefly upon fish; they are generally speaking a strong race of people + often meet in comparatively large bodies, not unlike the natives of Encounter Bay. They differ considerably in dialect + custom from the other tribe + the males have the distinguishing mark of a small ring or circle engraved on each shoulder. The Parnkalla tribe are spread over a far greater extent of country from Port Lincoln to the northward beyond 
Franklin Harbour and over the greater part of the interior country. They divide themselves again into two smaller tribes, viz. Wambirri yurarri, i.e. coast people and Battara yurarri, i.e. gum tree people, so called from their living in the interior country where the gum is plentiful. It is to be understood however, that these tribes are not so entirely separated as not to mix occasionally, on the contrary they often visit each other in small numbers. (Schürmann 1840-45: 143-5)

Schürmann touches on the relationship between Nawu and Barngarla people in numerous other letters (e.g. Schürmann 1840-45: 167, 195), and it is consistently implicit in his correspondence that Nawu people and country are primarily to the immediate south and west of Port Lincoln, and Barngarla people are at Port Lincoln and north from there.

It is possible, as was suggested by some during the Barngarla trial, that Barngarla people had only recently moved as far south as Port Lincoln in response to the novelty of the emerging white township.

Against this suggestion, in my view, is the fact that there is no mention in any of Schürmann's writings of disputes among Aboriginal people about ownership or authority in Port Lincoln. The overall image conveyed is one of generally peaceful coexistence between Nawu and Barngarla, or at least no more tension between those two groups than there appears to have been between coastal and inland Barngarla - that is, the Batara yurari and Wambirri yurari. For the most part, these tensions seem to have been fuelled by conflicts with Europeans. For example, it seems to have frequently been the Batara yurari who would attack homesteads or shepherds and the Wambirri yurari who would suffer the consequences of white retaliation, which in turn led to the latter being angry with the former.

The lack of perceivable conflict about traditional matters or, as Schürmann said, 'hereditary feuds' (something he had become alerted to during his time in Adelaide) suggests that whatever population movements may have happened in this area, the intra-Aboriginal situation was relatively stable by the time Schürmann lived at Port Lincoln, which was essentially at effective sovereignty. ${ }^{4}$

4 In the native title context, 'sovereignty' is the time in which the British Crown legally annexed land, which, for Eyre Peninsula and most of South Australia, was 1788. 'Effective sovereignty' refers to the time physical colonisation actually took place, and courts will usually use that as the relevant point from which to assess cultural change. 
In 1853, Schürmann left South Australia for Victoria, where he became the minister to a German congregation in Portland and eventually president of the Victorian district of the Evangelical Lutheran Synod of Australia. He died on 3 March 1893 while attending synod at Bethany, South Australia (Kneebone 2005).

\section{Conclusion}

Schürmann's ethnographic observations clearly have their limitations. His cultural biases inhibited his recording of religious narratives and quite possibly other cultural features, and, of course, he had not been trained as an ethnographic observer. Ultimately, creating an ethnographic record was not his main concern, but rather a means to an end. And yet his record contains a unique level of detail from a period of colonisation for which ethnographic information is largely absent. His intimate and personal relationships with Barngarla and Nawu people allowed Schürmann to convey insights not usually found outside dedicated anthropological fieldwork, which he pre-dated by more than half a century. His information on the traditional population patterns on Eyre Peninsula on the one hand cancelled out the migration argument against the Barngarla claim. On the other hand, it meant that areas south of Port Lincoln were not determined on behalf of Barngarla, because they were found to have been traditional Nawu country. As such, he joins an ever-increasing list of posthumous 'experts' in the native title process (Burke 2011). Ultimately, Schürmann has left a record that continues to offer valuable data to linguists, anthropologists and historians, and be of ongoing relevance to the descendants of the people with whom he worked.

\section{References}

Amery, R. 2000. Warrabarna Kaurna! Reclaiming an Australian language. Lisse, Netherlands: Swets \& Zeitlinger.

Berndt, R. 1985. Traditional Aborigines. In Natural History of Eyre Peninsula, Occasional Publications for the Royal Society of South Australia No. 4, (eds) C. R. Twidale, M. J. Tyler and M. Davies, pp. 127-38. Adelaide: Royal Society of South Australia. 
Burke, P. 2011. Law's Anthropology: From ethnography to expert testimony in native title. Canberra: ANU E Press.

Elkin, A. P. 1931. The social organization of South Australian tribes. Oceania 2: 44-73. doi.org/10.1002/j.1834-4461.1931.tb00022.x.

Hercus, L. and McCaul, K. 2004. Otto Siebert: The missionary ethnographer. Occasional Paper No. 3, (ed.) Walter Veit, pp. 36-50. Strehlow Research Centre, Alice Springs, NT.

Hercus, L. and Potezny, V. 1991. Locating Aboriginal sites: A note on JG Reuther and the Hillier map of 1904. Records of the South Australian Museum 24(2).

Hercus, L. and Simpson, J. 2001. The tragedy of Nauo. In Forty Years On: Ken Hale and Australian languages, (eds) J. Simpson, D. Nash, M. Laughren, P. Austin and B. Alpher, pp. 263-90. Canberra: Pacific Linguistics.

Howitt, A. W. 1996 [1904]. The Native Tribes of South-East Australia. Canberra: Aboriginal Studies Press.

Howitt, A. W. and Siebert, O. 1904. Legends of the Dieri and kindred tribes of Central Australia. Journal of the Anthropological Institute of Great Britain (34): 100-29.

Jones, P. 2002. Naming the dead heart: Hillier's map and Reuther's gazetteer of 2,468 place names in north-eastern South Australia. In The Land is a Map: Placenames of Indigenous origins in Australia, (eds) L. Hercus, F. Hodges and J. Simpson, pp. 187-200. Canberra: Pandanus Books.

Jones, P. and Sutton, P. 1986. Art and Land: Aboriginal sculptures of the Lake Eyre Basin. Adelaide: Wakefield Press.

Kenny, A. 2013. The Aranda's Pepa: An introduction to Carl Strehlow's masterpiece Die Aranda- und Loritja-Stämme in Zentral-Australien (1907-1920). Canberra: ANU E Press. 
Kneebone, H. 2005. Teichelmann, Christian Gottlieb (1807-1888). In Australian Dictionary of Biography. Canberra: National Centre of Biography, The Australian National University. Available from: adb.anu.edu.au/biography/teichelmann-christian-gottlieb-13213/ text23925. Published first in hardcopy 2005. Accessed online 19 January 2016.

Lockwood, C. 2011. A vision frustrated: Lutheran missionaries to the Aborigines of South Australia 1838-1853. In Germans: Travelers, settlers and their descendants in South Australia, (ed.) P. Monteath, pp. 17-40. Adelaide: Wakefield Press.

Matthews, R. M. 1900. Divisions of the South Australia Aborigines. Proceedings of the American Philosophical Society 39: 78-93.

Meyer, H. A. E. 1843. Vocabulary of the Language Spoken by the Aborigines of the Southern and Eastern Portions of the Settled Districts of South Australia. Adelaide: James Allen.

Meyer, H. A. E. 1846. Manners and Customs of the Aborigines of the Encounter Bay Tribe: South Australia. Adelaide: State Library of South Australia.

Reuther, J. G. 1976. The Diari. Translated by Rev. P. A. Scherer. Unpublished ms, AA226, South Australian Museum, Adelaide.

Sahlins, M. 1972. Stone Age Economics. London: Tavistock Publications.

Schürmann, C. 1840-45. Correspondence of missionary Clamor Schürmann from Port Lincoln. Unpublished ms, Lutheran Archives, Adelaide.

Schürmann, C. 1844. Vocabulary of the Parnkalla Language: Spoken by the natives inhabiting the western shores of Spencer's Gulf. Adelaide: Dehane.

Schürmann, C. 1879 [1846]. The Aboriginal tribes of Port Lincoln in South Australia: Their mode and life, manners, customs etc. In The Native Tribes of South Australia, (ed.) J. Woods, pp. 209-51. Adelaide: E. S. Wigg \& Son.

Schurmann, E. 1987. I'd Rather Dig Potatoes: Clamor Schurmann and the Aborigines of South Australia 1838-1853. Adelaide: Lutheran Publishing House. 
Siebert, O. 1910. Sagen und Sitten der Dieri und Nachbarstämme in Zentral-Australien. Globus 97(3): 44-50; 97(4): 53-9.

Strehlow, C. 1907-1920. Die Aranda- und Loritja-Stämme in ZentralAustralien. 7 vols. Frankfurt am Main: Joseph Baer \& Co.

Strehlow, T. G. H. 1971. Songs of Central Australia. Sydney: Angus \& Robertson.

Teichelmann, C. G. and Schürmann, C. 1840. Outlines of a grammar, vocabulary, and phraseology, of the Aboriginal language of South Australia, spoken by the natives in and for some distance around Adelaide. Adelaide.

Tindale, N. 1974. Aboriginal Tribes of Australia. Canberra: Australian National University Press.

Völker, H. 1999. Projektion des Fremden: Beiträge deutscher lutherischer Missionare zur Darstellung der australischen Urbevölkerung um 1900-Johann Georg Reuther, Carl Strehlow, Otto Siebert. PhD thesis. Albert Ludwig University of Freiburg, Freiburg im Breisgau, Germany. 
This text is taken from German Ethnography in Australia, edited by Nicolas Peterson and Anna Kenny, published 2017 by ANU Press, The Australian National University, Canberra, Australia.

dx.doi.org/10.22459/GEA.09.2017.03 